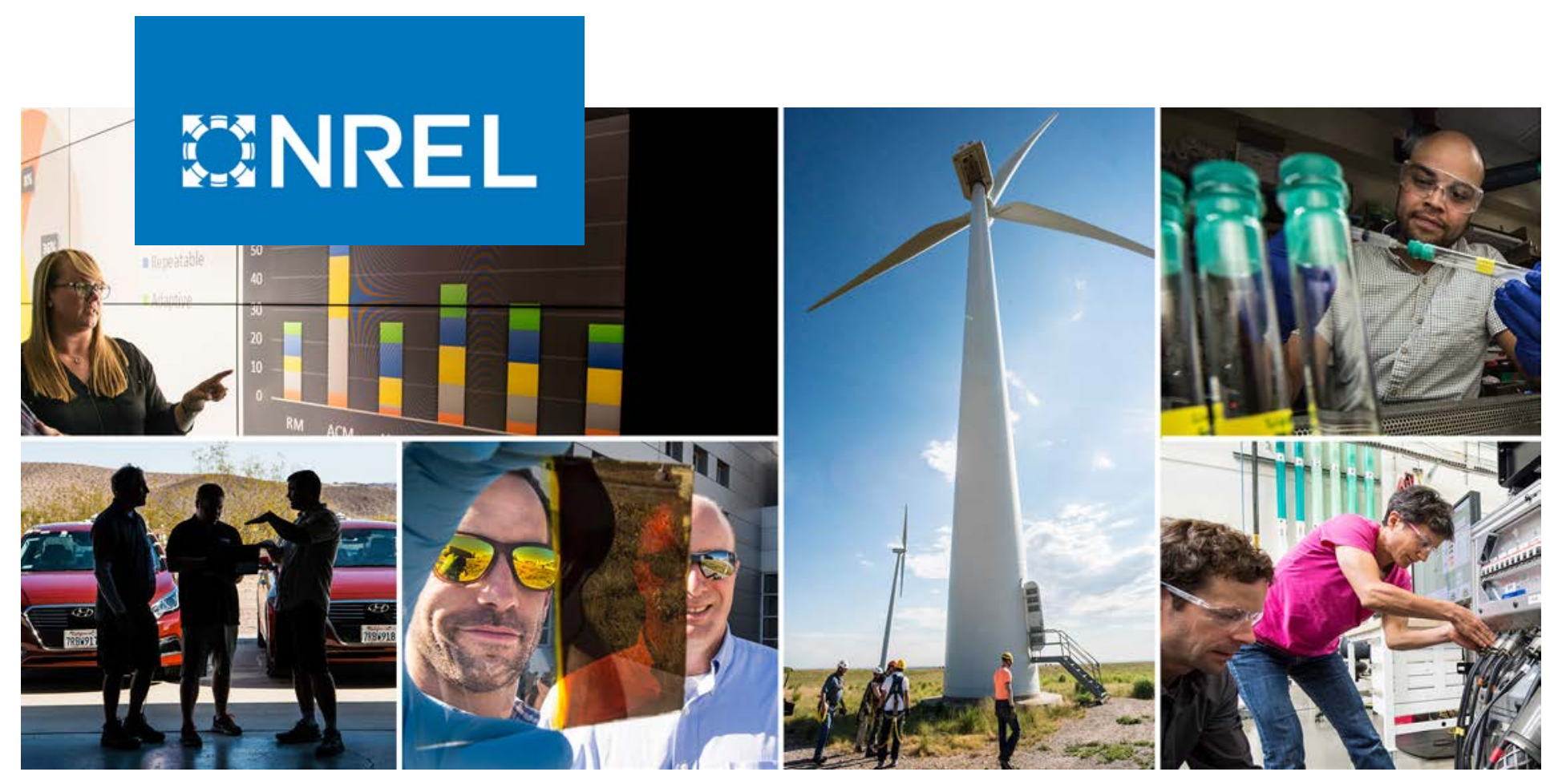

\title{
FERC Hydropower Licensing: A Review of Utilization of the ILP, TLP, and ALP
}

Aaron Levine and Austin Flanagan

National Renewable Energy Laboratory

NREL is a national laboratory of the U.S. Department of Energy

Office of Energy Efficiency \& Renewable Energy

Operated by the Alliance for Sustainable Energy, LLC

This report is available at no cost from the National Renewable Energy Laboratory (NREL) at www.nrel.gov/publications.

\section{Technical Report}

NREL/TP-6A20-71982

January 2019 


\title{
GNREL
}

\section{FERC Hydropower Licensing: A Review of Utilization of the ILP, TLP, and ALP}

\author{
Aaron Levine and Austin Flanagan
}

National Renewable Energy Laboratory

\section{Suggested Citation}

Levine, Aaron and Austin Flanagan. 2019. FERC Hydropower Licensing: A Review of Utilization of the ILP, TLP, and ALP. Golden, CO: National Renewable Energy Laboratory. NREL/TP-6A20-71982. https://www.nrel.gov/docs/fy19osti/71982.pdf.

NREL is a national laboratory of the U.S. Department of Energy Office of Energy Efficiency \& Renewable Energy Operated by the Alliance for Sustainable Energy, LLC

This report is available at no cost from the National Renewable Energy Laboratory (NREL) at www.nrel.gov/publications.

Contract No. DE-AC36-08GO28308
Technical Report NREL/TP-6A20-71982 January 2019

National Renewable Energy Laboratory 15013 Denver West Parkway Golden, CO 80401 303-275-3000 • www.nrel.gov 


\section{NOTICE}

This work was authored by the National Renewable Energy Laboratory, operated by Alliance for Sustainable Energy, LLC, for the U.S. Department of Energy (DOE) under Contract No. DE-AC36-08GO28308. Funding provided by the U.S. Department of Energy Office of Energy Efficiency and Renewable Energy Water Power Technologies Office. The views expressed herein do not necessarily represent the views of the DOE or the U.S. Government.

This report is available at no cost from the National Renewable Energy Laboratory (NREL) at www.nrel.gov/publications.

U.S. Department of Energy (DOE) reports produced after 1991 and a growing number of pre-1991 documents are available free via www.OSTI.gov.

Cover Photos by Dennis Schroeder: (clockwise, left to right) NREL 51934, NREL 45897, NREL 42160, NREL 45891, NREL 48097, NREL 46526.

NREL prints on paper that contains recycled content. 


\section{Acknowledgments}

The authors gratefully acknowledge the EERE Water Power Technologies Office for its funding support. We thank Frank Walter and John "Jack" Wadleigh for their research assistance. We also thank the following reviewers for their time and expertise: Corey Vezina and Tim Welch, U.S. Department of Energy, Taylor Curtis, Jaqueline Cochran, Dan Bilello, Mary Lukkonen (editor), National Renewable Energy Laboratory. 


\section{List of Acronyms}

$\begin{array}{ll}\text { ALP } & \text { Alternative Licensing Process } \\ \text { BLM } & \text { Bureau of Land Management } \\ \text { DOI } & \text { Department of the Interior } \\ \text { EA } & \text { Environmental Assessment } \\ \text { EIS } & \text { Environmental Impact Statement } \\ \text { FERC } & \text { Federal Energy Regulatory Commission } \\ \text { FPA } & \text { Federal Power Act } \\ \text { FY } & \text { Fiscal Year } \\ \text { ILP } & \text { Integrated Licensing Process } \\ \text { LOPP } & \text { Lease of Power Privilege } \\ \text { NEPA } & \text { National Environmental Policy Act of 1969 } \\ \text { NGO } & \text { Non-Governmental Organization } \\ \text { NOAA } & \text { National Oceanic and Atmospheric Administration } \\ \text { NOI } & \text { Notice of Intent } \\ \text { PAD } & \text { Pre-Application Document } \\ \text { TLP } & \text { Traditional Licensing Process }\end{array}$




\section{Executive Summary}

A preliminary consideration for license applicants seeking to develop non-federal hydropower projects includes determining whether the Federal Energy Regulatory Commission (FERC) has authority over the development, and if so, what licensing procedures are required or may be an option for authorizing the project.

Projects subject to FERC jurisdiction, which do not meet the qualification requirements for an exemption from FERC hydropower licensing, must complete the FERC hydropower licensing process utilizing one of FERC's three licensing processes: The Integrated Licensing Process (ILP), Traditional Licensing Process (TLP), or Alternative Licensing Process (ALP). Effective after July 23, 2005, the ILP became the default hydropower licensing process under the FPA [18 CFR $\S 5.3(\mathrm{a})(2)]$ and any license applicant seeking to use the TLP or ALP is now required to submit to FERC a request to use the TLP or ALP with their Notice of Intent (NOI) and PreApplication Document (PAD) and receive approval before initiating either of those processes [18 CFR $\S 5.3(\mathrm{a})(2)]$.

The report addresses:

- Distinctions among FERC's three licensing processes

- The regulatory requirements to receive approval to use the TLP or ALP

- Case studies of projects that FERC granted/denied approval to use the TLP or ALP processes

- General advantages and challenges associated with each licensing process.

As demonstrated through the case studies in this report, the ALP and TLP are still both utilized licensing processes. However, they may not be appropriate for all projects and these case studies highlight that FERC does use its authority to deny the TLP in favor of the default ILP where it finds the TLP is not suitable for the potential complexities, controversy, study disputes, and/or other pertinent licensing factors associated with the hydropower project. 


\section{Table of Contents}

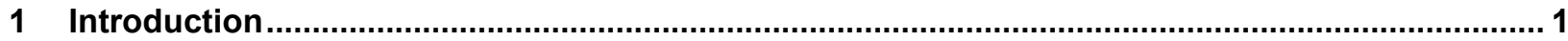

2 Overview of the FERC Hydropower Licensing Process ......................................................... 2

2.1 The Three FERC Hydropower Licensing Process Types........................................................2

2.1.1 The Integrated Licensing Process (Default Process) ................................................... 2

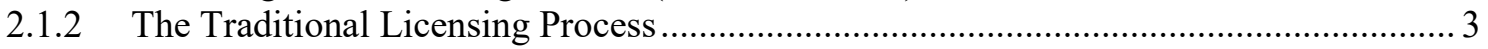

2.1.3 The Alternative Licensing Process .................................................................................. 4

2.2 Procedures for Requesting to Use the TLP or ALP Licensing Processes and FERC's Response 5

2.2.1 Request to Use the TLP or ALP Licensing Processes....................................................... 5

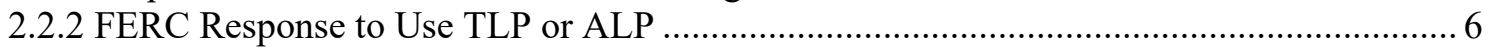

3 Licensing Process Request/Response Case Studies............................................................ 7

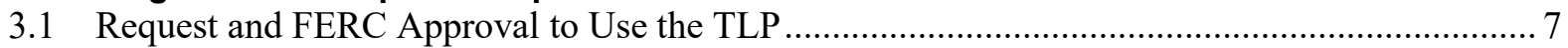

3.1.1 Request and FERC Approval to Use the TLP for Original License............................... 7

3.1.2 Request and FERC Approval to Use the TLP for New License (Relicense) ................... 8

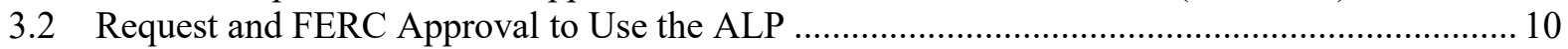

3.2.1 Request and FERC Approval to Use the ALP for Original License ............................. 10

3.2.2 Request and FERC Approval to Use the ALP for New License (Relicense)................. 11

3.3 Request and FERC Denial to Use the TLP (Requirement to Use the ILP) ............................. 12

3.3.1 Request and FERC Denial to Use the TLP for Original License .................................. 12

3.3.2 Request and FERC Denial to Use the TLP for New License (Relicense)...................... 13

4 Potential Advantages and Challenges of Each Licensing Process .......................................... 17

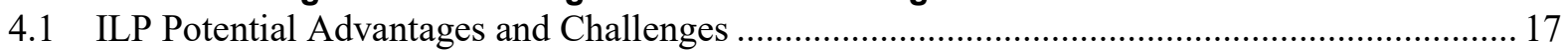

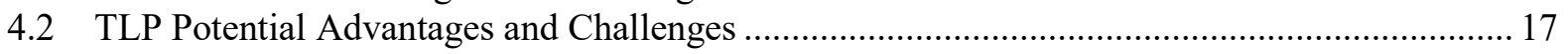

4.3 ALP Potential Advantages and Challenges ......................................................................... 18

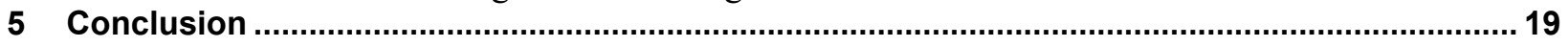

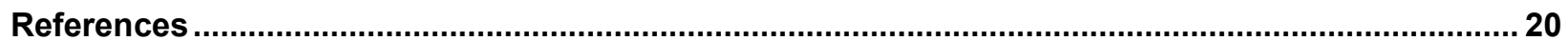




\section{Introduction}

A preliminary consideration for license applicants seeking to develop non-federal hydropower projects includes determining whether the Federal Energy Regulatory Commission (FERC) has authority over the development, and if so, what licensing procedures are required or may be an option for authorizing the project.

Under the Federal Power Act (FPA), FERC administers approvals of certain non-federal hydropower projects (see Title 1 of the FPA, 16 USC Ch. 12). Generally, FERC's hydropower licensing authority includes non-federal hydropower projects:

- Located on navigable waters of the United States

- Occupying U.S. land

- Utilizing surplus water or water power of a U.S. government dam

- Located on a stream over which Congress has Commerce Clause jurisdiction, where project construction or expansion occurred on or after August 26, 1935, and the project affects the interests of interstate or foreign commerce.

(16 USC § 797(e))

Under certain specified criteria, a project may receive an exemption from FERC licensing as a qualifying conduit hydropower facility, a small conduit hydroelectric facility (40 MW or less), or a small hydroelectric facility (10 MW or less) (16 USC $\S 823 \mathrm{a}(\mathrm{a}), 16 \mathrm{USC} \S 823 \mathrm{a}(\mathrm{b}), 16 \mathrm{USC} \S$ 2705). Projects that do not meet the qualification requirements for an exemption from FERC hydropower licensing must complete the FERC hydropower licensing process utilizing one of FERC's three licensing processes: The Integrated Licensing Process (ILP), Traditional Licensing Process (TLP), or Alternative Licensing Process (ALP). Effective after July 23, 2005, the ILP became the default hydropower licensing process under the FPA [18 CFR § 5.3(a)(2)]. As a result, any license applicant seeking to use the TLP or ALP is now required to submit to FERC a request to use the TLP or ALP with their Notice of Intent (NOI) and Pre-Application Document (PAD) and receive approval before initiating either of those processes [18 CFR § 5.3(a)(2)].

Where the project will require a FERC hydropower license, determining which licensing procedures best fit the specific resource and stakeholder concerns can play an important role in effectively and efficiently licensing the project.

In order to provide stakeholders a better understanding of each licensing process type, this report explores:

- The distinctions between FERC's three licensing processes (ILP, TLP, and ALP)

- The required procedures and review criteria to receive approval to use the TLP or ALP

- Case studies highlighting the rationale license applicants provided in a request to use the TLP or ALP and FERC's response

- Potential advantages and challenges associated with each FERC licensing process. 


\section{Overview of the FERC Hydropower Licensing Process}

This section provides an overview of high-level differences among FERC's three hydropower licensing process types and the procedural requirements to use the TLP or ALP procedures.

\subsection{The Three FERC Hydropower Licensing Process Types}

FERC hydropower regulations include three licensing process types for authorizing non-federal hydropower projects subject to FERC jurisdiction and not eligible for an exemption from FERC licensing. Each of the three licensing processes described in more detail below may be wellsuited for licensing a hydropower project based on an individual project's specifications.

\subsubsection{The Integrated Licensing Process (Default Process)}

In 2003, FERC established the ILP licensing process for non-federal hydropower projects under the FPA to provide a predictable, efficient, and timely licensing process (FERC 2015b). ${ }^{1}$ The ILP incorporated elements of both the TLP and the ALP (discussed in Sections 2.1.2 and 2.1.3, respectively) to create a licensing process that is both collaborative and structured. The ILP may be the preferred licensing process where a project involves controversial and/or complex issues, stakeholder support for the proposed project is uncertain or stakeholders have conflicting values, and/or a structured timeline is preferred (FERC 2015b).

The ILP imposes defined deadlines for all participants in the licensing process (including FERC, the licensee, and other participating stakeholders) for preparing and reviewing licensing documents (FERC 2017c; 18 CFR Part 5).

The ILP provides license applicants with increased assistance/involvement from FERC staff during the pre-filing phase of the FERC licensing process. Under the ILP, FERC staff become involved earlier in the pre-filing stages of the licensing process to improve coordination between resource agencies and to assist license applicants with the preparation of the FERC license application and remain involved throughout the process (FERC 2017c; 18 CFR Part 5).

A license applicant using the ILP must engage with federal and state agencies, Indian tribes, and the public early in the process to develop a study plan (i.e., list of required studies) that the licensee must complete in order to adequately evaluate potential engineering, economic, or environmental issues associated with the hydropower project (18 CFR Part 5).

The ILP combines the licensee's pre-filing consultation with FERC's National Environmental Policy Act of 1969 (NEPA) scoping process (18 CFR Part 5). Under the ILP, FERC must initiate NEPA scoping within 60 days of receiving the license applicant's NOI to file for a FERC license (18 CFR $\S 5.8(\mathrm{a}) \&(\mathrm{c})$ ). In addition, the license applicant files a draft study plan only after all pre-application stakeholder consultations are complete and FERC concludes the NEPA scoping

\footnotetext{
${ }^{1}$ Effective after July 23, 2005, the ILP became the default licensing process for FERC hydropower licensing under the FPA [18 CFR $\S 5.3(\mathrm{a})(2)]$.
} 
process (18 CFR $\S$ Part 5). Participating stakeholders then meet to discuss the draft study plan and to resolve any remaining concerns (18 CFR 5.11(e)). The ILP includes an informal dispute resolution process available to all participants and a formal dispute resolution process available to agencies with mandatory conditioning authority under the FPA (i.e., authority under FPA Section 4(e), Section 18, or any agency with authority to issue a Section 401 water quality certification under the Clean Water Act). The formal dispute resolution process provides the FERC's Director of the Office of Energy Projects with binding authority to issue a determination amending the approved study plan (18 CFR $\S 5.14(1))$.

Conducting NEPA scoping during the pre-application phase, before the license applicant files a study plan, may help to ensure consistency between the license applicant's study plan and FERC's environmental review and may reduce the number of study requests made later in the FERC licensing process, after the license applicant has filed a FERC license application.

\subsubsection{The Traditional Licensing Process}

In 1985, FERC developed the TLP to guide the licensing of non-federal hydropower projects, which has seen modifications over time, including in 2003 in conjunction with the promulgation of the ILP rule. Under the TLP, the license applicant directs the pre-filing phase of the FERC licensing process (e.g., consultations with state and federal agencies, public meetings, necessary studies) (see 18 CFR $\S 4.38$ and 18 CFR $\S 16.8$ ). The license applicant must request FERC's authorization to use the TLP instead of the ILP and must provide notice of the request to affected resource agencies, Indian tribes, and interested members of the public (see 18 CFR $\S 5.3$ or Section 2.2 for more details).

The TLP does not set rigid timeframes for completing many pre-filing activities, licensing activities, project review, stakeholder comments, and/or decision making. Under the TLP, FERC staff generally do not participate in the pre-application phase, but rather only after the license applicant files a license application and the post-application phase of the licensing begins. ${ }^{2}$

During the TLP pre-filing phase, the license applicant must provide federal and state resource agencies and Indian tribes with information about the proposed hydropower project. These parties help the license applicant to create a study plan, identifying any studies that must be completed in order to determine the project's effects on water resources, fish and wildlife, cultural resources, recreation, and other resources (see $18 \mathrm{CFR} \S 4.38$ and 18 CFR $\S 16.8$ ). However, consultation with interested stakeholders may be limited during the TLP's applicantled pre-filing phase. ${ }^{3}$ The TLP includes dispute resolution available only upon request to agencies and affected tribes, but FERC's Director of the Office of Energy Projects opinion is advisory in nature and not binding (FERC 2017c; 18 CFR $\S 4.38(b)(6)(i v)$ ).

Under the TLP, FERC initiates the NEPA scoping process during the post-filing phase, after FERC has accepted the license application for filing and participating stakeholders have had an

\footnotetext{
${ }^{2}$ FERC staff is available for education and other guidance during the pre-filing phase of the TLP (FERC 2017c).

${ }^{3}$ Some license applicants have used an "enhanced" version of the TLP to incorporate full public participation into the pre-filing consultation phase (see Layman et al. 2006; Payne 2017).
} 
opportunity to provide comments and recommendations for the FERC license (FERC 2004). However, because FERC conducts NEPA scoping after the license applicant files the final license application, ${ }^{4}$ this flexibility may also create risks, potential delays, and unpredictable outcomes because it provides an opportunity for FERC, resource agencies, and other participating stakeholders to request additional studies later in the licensing process (Cowan n.d.).

\subsubsection{The Alternative Licensing Process}

In 1997, the ALP was established in an effort to streamline pre-filing consultation and NEPA requirements, facilitate greater participation and communication among stakeholders, and promote cooperation among project stakeholders (18 CFR $\S 4.34(i)(2))$.

A primary purpose of the ALP is to assist parties in developing a settlement agreement that may provide a framework for the FERC license (18 CFR $\S 4.34(\mathrm{i})(2))$. The ALP combines pre-filing consultation, the NEPA process, and administrative processes associated with other statutory compliance requirements into a single process (18 CFR $\S 4.34(\mathrm{i})$ ). The ALP may be suitable where a flexible timeframe and greater public participation and support is needed for the proposed project (FERC 2015b).

As with the TLP, the license applicant must request FERC's permission to use the ALP (18 CFR $\S 5.3)$. To receive FERC's approval to use the ALP, the license applicant must establish stakeholder support for using the ALP process (see 18 CFR $\S 5.3$ and Section 2.2 for more detail).

The ALP may be more suitable where the license applicant and other interested stakeholders need more flexibility in completing the steps necessary in the pre-filing process. However, as with the TLP, this flexibility provides an opportunity for FERC, the resource agencies, and other participating stakeholders to request additional studies later on in the licensing process. The ALP includes dispute resolution available only upon request to agencies and affected tribes, but FERC's Director of the Office of Energy Projects opinion is advisory in nature and not binding (FERC 2017c; 18 CFR § 4.34(i)(6)(vii)).

FERC plays an advisory role during the ALP's pre-filing phase, as the license applicant and other interested parties work to develop a collaborative study plan (FERC 2017c). The ALP requires early and intensive collaboration among participating stakeholders, including FERC staff. Under the ALP, the license applicant cooperates with interested stakeholders during the pre-filing phase to develop both the license application and typically a preliminary draft NEPA document [environmental assessment (EA) or environmental impact statement (EIS)] (18 CFR § 4.34(i)).

Under the ALP, the license applicant conducts environmental scoping during the pre-filing consultation phase and generally submits a draft EA or EIS - including any preliminary fish and wildlife agency comments, conditions, and recommendations - with the FERC license 
application (18 CFR $\S 4.34(i)(6))$. Although the license applicant files a preliminary draft NEPA document, FERC reviews the draft for consistency with FERC's environmental review requirements, performs an environmental review of the proposed project, and completes the final NEPA document (FERC 2015b).

\subsection{Procedures for Requesting to Use the TLP or ALP Licensing Processes and FERC's Response}

As discussed in Section 2.1.1, the ILP is the default FERC hydropower licensing process. This section discusses the regulatory process for requesting to use the TLP or ALP licensing processes and FERC's response to the TLP or ALP request.

\subsubsection{Request to Use the TLP or ALP Licensing Processes}

While the ILP is the default FERC licensing process, license applicants may request to use the TLP or ALP procedures. Any license applicant filing an NOI pursuant to 18 CFR $\S 5.5$ and a PAD pursuant to $18 \mathrm{CFR} \S 5.6$ after July 23, 2005, must request authorization from FERC to use the TLP or ALP procedures in 18 CFR Part 4 and Part 16, respectively (18 CFR $\S 5.3(\mathrm{a})(2))$. The license applicant may file the request with its NOI pursuant to 18 CFR $\S 5.5$ (18 CFR $\S 5.3(b)$ ).

Where a license applicant requests to use the TLP, the request must include justification for using the TLP, along with any existing written comments on the license applicant's proposal and associated responses (18 CFR $\S 5.3(\mathrm{c})(1)(\mathrm{i}))$. The request to use the TLP should address the:

- Likelihood of timely license issuance

- Complexity of the resource issues

- Level of anticipated controversy

- Relative cost of the traditional process [TLP] compared to the integrated process [ILP]

- Amount of available information and potential for significant disputes over studies

- Other factors believed by the [license] applicant to be pertinent.

18 CFR $\S 5.3(\mathrm{c})(1)(\mathrm{ii})$

Where a license applicant requests to use the ALP, the request must:

- "Demonstrate that a reasonable effort has been made to contact all agencies, Indian tribes, and others affected by the [license] applicant's request, and that a consensus exists that the use of alternative procedures is appropriate under the circumstances;

- Submit a communications protocol, supported by interested entities, governing how the [license] applicant and other participants in the pre-filing consultation process, including the Commission staff, may communicate with each other regarding the merits of the potential [license] applicant's proposal and proposals and recommendations of interested entities; and

- Provide a copy of the request to all affected resource agencies and Indian tribes and to all entities contacted by the [license] applicant that have expressed an interest in the alternative pre-filing consultation process."

$18 \mathrm{CFR} \S 5.3(\mathrm{c})(2)$ 
The license applicant must publish any request to use the TLP or ALP no later than the filing date of the NOI. The notice must:

- Disclose the filing date of the request to use the TLP or ALP (along with the NOI and PAD)

- Briefly summarize the NOI, PAD, and request to use the TLP or ALP

- Include the license applicant's contact information, the type of proposed facility, the proposed facility location, and the places where the PAD is available for inspection and reproduction

- Include a statement that comments on the request to use the TLP or ALP are due to FERC and the license applicant no later than 30 days after the filing date

- State that comments on the request to use the TLP or ALP should address, as appropriate, the license applicant's justification pursuant to 18 CFR $\S 5.3(\mathrm{c})(2)$

- State that respondents must submit comments to the Secretary of the Commission (FERC) in accordance with the filing procedures posted on FERC's website.

$18 \mathrm{CFR} \S 5.3(\mathrm{~d})(2)$

The license applicant must also provide a copy of the request to use the TLP or ALP to all affected resource agencies, Indian tribes, and members of the public likely to be interested in the proceeding (18 CFR $\S 5.3(\mathrm{~d})(1)$ ). Comments on the request to use the TLP or ALP must be filed with FERC within 30 days of the filing date of the request (18 CFR $\S 5.3(d)(1))$.

\subsubsection{FERC Response to Use TLP or ALP}

FERC must respond via notice to any license applicant request to use the TLP or ALP within 60 days of filing the NOI, PAD, and licensing process request (18 CFR $\S 5.8(\mathrm{a})$ ). The FERC notice must include the decision of FERC's Director of the Office of Energy Projects on any request to use the TLP or ALP, along with a notice of commencement of proceedings and the initial scoping document (i.e., Scoping Document 1$)^{5}(18$ CFR $\S 5.8(\mathrm{~b})(1))$.

\footnotetext{
${ }^{5}$ The initial scoping document identifies FERC staff's preliminary list of resource concerns and other issues that
} will be addressed as part of the NEPA analysis. 


\section{Licensing Process Request/Response Case Studies}

This section highlights examples of previous TLP and ALP licensing process requests to provide additional insight into why license applicants have previously requested to use the TLP or ALP licensing processes for various projects [e.g., original license, new license (i.e., re-licensing), run-of-river, pumped storage] and whether FERC has determined if such requests were appropriate. In order to gain additional insight on projects that have required the ILP process, this section highlights examples of projects in which FERC denied the request to use the TLP process and instead required the license applicant to proceed under the default ILP procedures.

\subsection{Request and FERC Approval to Use the TLP}

As discussed in Section 2.2.1, a request to use the TLP should address the:

- Likelihood of timely license issuance

- Complexity of the resource issues

- Level of anticipated controversy

- Relative cost of the traditional process [TLP] compared to the integrated process [ILP]

- Amount of available information and potential for significant disputes over studies

- Other factors believed by the [license] applicant to be pertinent.

18 CFR $\S 5.3(\mathrm{c})(1)(\mathrm{ii})$

This section highlights examples of license applicant requests and FERC approvals to use the TLP for both original licensing and new licensing (relicensing).

\subsubsection{Request and FERC Approval to Use the TLP for Original License}

In June 2016, the license applicant for the Banks Lake Pumped Storage Project (FERC No. 14329) filed an NOI, PAD, and request to use the TLP for an original license to construct a pumped storage project located on Banks Lake (created from two existing dams - the North and Dry Falls) and Franklin D. Roosevelt Lake (created by the Grand Coulee Dam) in Douglas and Grant Counties, Washington (CBHP 2016). The project, located on federal lands managed by the Bureau of Reclamation (Reclamation), proposed to use Banks Lake as an upper reservoir and Franklin D. Roosevelt Lake as a lower reservoir to create a 500-MW (scalable to 1,000-MW) pumped storage project that would require construction of a new powerhouse, penstock, and transmission line (CBHP 2016).

In the PAD, the license applicant included potential soil erosion, weakening of thermal stratification, disturbing habitat for endangered or threatened species, potential for entrainment from lower intake, and disturbing migratory fish populations as existing environmental issues (CBHP 2016). Specifically, the license applicant identified three threatened species (one of which, the bull trout, was likely to be affected by entrainment) and one species listed as a candidate that may be present at the proposed project. Proposed studies in the PAD included operation modeling of soil and water fluctuations (which include any impact associated with recreation from increased water fluctuations), a limnology study of the two reservoirs, a desktop entrainment model, and consultation with the State Historic Preservation Officer and Tribes for 
development of a Historic Properties Management Plan, which would include cultural and historic property surveys.

The license applicant's request to use the TLP for an original license cited the following factors:

- Likelihood of timely license issuance: The license applicant believed use of the TLP would provide federal, state, and local agencies with a manageable timeframe and assist FERC to issue a timely license. In addition, because the project required both a FERC license and a Reclamation Lease of Power Privilege (LOPP), the TLP would allow for more flexibility in coordinating work load and schedule for the two regulatory processes.

- Complexity of the resource issues and level of anticipated controversy: During pre-PAD consultation with agencies and other stakeholders, the license applicant identified additional information required on the existing environment but did not identify resource issues that appeared to be complex or controversial.

- Relative cost of the TLP to the ILP: The license applicant believed the TLP would allow for completion of the license application in less time and, therefore, less cost than the ILP.

- Amount of available information and potential for significant disputes over studies: Sufficient information was available on many of the resources in the surrounding environment, but the license applicant acknowledged that some resources would require further study and supplementation.

- Other factors believed to be pertinent: The license applicant believed the TLP would allow the license applicant to coordinate the FERC licensing process and the Reclamation LOPP process more flexibly than the ILP.

(CBHP 2016)

In FERC's response granting the license applicant's request to use the TLP, it noted that no comments were received in response to the TLP request or the PAD, and based on the information provided, the complexity of resource issues and level of anticipated controversy was expected to be minimal (FERC 2016b).

\subsubsection{Request and FERC Approval to Use the TLP for New License (Relicense)}

In August 2016, the existing licensee of the Rio Blanco Hydroelectric Project (FERC No. 663) filed an NOI, PAD, and request to use the TLP for a new license (relicense) of an existing 5-MW run-of-river facility in eastern Puerto Rico, originally licensed in August 1991 (PREPA 2016). The project, located on 2.2 acres of federal land in the El Yunque National Forest managed by the U.S. Forest Service, included five dams, one reservoir with a spillway section that is $90 \mathrm{ft}$. $\mathrm{x}$ $55 \mathrm{ft}$. within an intake section of $27 \mathrm{ft}$., a steel penstock, a powerhouse with two generating units, and a concrete 240-ft. tailrace (PREPA 2016).

In the PAD, the licensee included potential disturbance to several plant and animal species that are threatened or endangered and adverse effects to water quality caused by erosion as existing environmental issues (PREPA 2016). Because the project has been in existence for nearly 100 years and the licensee did not propose any changes, the licensee did not intend to conduct field studies, modeling, or other detailed analyses. Nonetheless, the licensee did intend to collect information on water quality for specific analytes, collect information on local and unrecognized 
tribal resources and interests, and identify Commonwealth-listed threatened or endangered species.

The licensee's request to use the TLP for a new license cited the following factors:

- Likelihood of timely license issuance: The licensee did not anticipate proposing an expansion or change in project operations during relicensing, nor did it anticipate any significant resource issues arising. As a result, the licensee believed FERC could issue a timely license using the TLP.

- Complexity of the resource issues: None of the resource issues associated with the relicensing were viewed as particularly complex. The portion of the project within the El Yunque National Forest is operated consistently with applicable U.S. Forest Service management requirements. In addition, no significant environmental impacts have occurred during the initial license term, and because the project did not plan to expand or change project operations, no significant impacts were anticipated.

- Level of anticipated controversy: The licensee did not anticipate any significant controversies because the project did not involve complex resource issues. Any project-related issues appeared to be identifiable and resolvable via consolations with agencies and other stakeholders.

- Relative cost of the TLP to the ILP: The licensee believed the TLP would be a more efficient use of time because of the low likelihood of significant issues and study requirements. Cost savings were expected to result from fewer meetings, reports, and FERC filing requirements when compared to the ILP.

- Amount of available information and potential for significant disputes over studies: The licensee compiled a substantial amount of information on environmental resources in the project area, which formed the basis of the submitted PAD. The licensee did not anticipate any complex issues and fully intended to consult with applicable agencies and stakeholders to solicit input. As a result, the licensee did not anticipate any significant study disputes that would require the use of the ILP.

- Other factors believed to be pertinent: FERC requested that the licensee consider the use of the TLP in a February 2015 letter.

(PREPA 2016)

During the notice and comment period for the NOI, PAD, and TLP request, the U.S. Forest Service submitted a comment requesting use of the default ILP. The Forest Service did not believe the licensee's request to use the TLP included support for assertions regarding project complexity, level of controversy, or study needs and disputes. In addition, the U.S. Forest Service noted current license concerns with minimum instream flows and the rate of sediment accumulation as well as potential recreational and cultural resource issues discovered during an ongoing Forest Plan revision process (USDA FS 2016).

Despite these concerns, FERC granted the licensee's request to use the TLP for the new license. In FERC's response granting the licensee's TLP request, it noted that the concerns raised by the U.S. Forest Service are common to most relicensing proceedings, and FERC found no indication of a need for complex studies that would require early scoping and study plan determinations under the ILP (FERC 2016a). In addition, FERC noted that the TLP provides a framework for conducting studies and a provision for agencies and affected tribes to request dispute resolution where there are disagreements over studies. As a result, FERC granted the TLP request, stating 
that the complexity of resource issues was likely to be low and anticipated controversy and disputes over studies minimal (FERC 2016a).

\subsection{Request and FERC Approval to Use the ALP}

As discussed in Section 2.2.1, a request to use the ALP should:

- "Demonstrate that a reasonable effort has been made to contact all agencies, Indian tribes, and others affected by the [license] applicant's request, and that a consensus exists that the use of alternative procedures is appropriate under the circumstances;

- Submit a communications protocol, supported by interested entities, governing how the [license] applicant and other participants in the pre-filing consultation process, including the Commission staff, may communicate with each other regarding the merits of the potential [license] applicant's proposal and proposals and recommendations of interested entities; and

- Provide a copy of the request to all affected resource agencies and Indian tribes and to all entities contacted by the [license] applicant that have expressed an interest in the alternative pre-filing consultation process."

$18 \mathrm{CFR} \S 5.3(\mathrm{c})(2)$

This section highlights examples of license applicant requests and FERC approvals to use the ALP for original licensing and new licensing (relicensing).

\subsubsection{Request and FERC Approval to Use the ALP for Original License}

In March 2009, the license applicant for the Takatz Lake Hydroelectric Project (FERC No. 13234) filed an NOI, PAD, and request to use the ALP for an original license to construct a 27MW hydropower project located on Baranof Island, approximately 20 miles from Sitka, Alaska. The project, as envisioned, included the creation of a concrete $200-\mathrm{ft}$. arch dam and $30-\mathrm{ft}$. secondary dam, expansion of an existing reservoir, a spillway, a gate structure intake into a 2,800-ft. long 6.5-ft x 7-ft. tunnel, a 1,000-ft. long x 72-inch diameter steel penstock, a powerhouse with two generating units, a tailrace, and a 21-mile long transmission line (City 2009).

Though extensive detail was not given, the license applicant listed eight existing environmental issues surrounding the project, including effects of altered streamflow in Takatz Creek on anadromous fish, water quality effects of construction on potentially affected water bodies, and effects of blasting necessary for road and tunnel construction (City 2009). Proposed studies in the PAD included baseline studies of fish and wildlife populations and their habitats, baseline plant surveys, hydrologic studies of streamflow, water quality studies, an inventory of cultural resources, and research on existing aesthetic information.

The license applicant's request to use the ALP for an original license cited the following factors:

- The license applicant recently completed all substantive work on relicensing the Blue Lake Hydro Project (FERC No. 2230) using the ALP. Use of the ALP on Blue Lake was "highly successful and created good working relationships and communication" among the license applicant and stakeholders, many of whom will be the same for the Takatz Lake Project. 
- Use of the ALP would afford a more flexible schedule within which to complete energy planning at the local and regional levels.

In addition, the license applicant noted compliance with the required ALP request factors listed in 18 CFR $\S 4.34(i)(3)$. In furtherance of these factors, the license applicant stated that it distributed a draft communications protocol to the project stakeholder list describing the licensing alternatives and requested comment in writing on use of the ALP. Notice respondents, including the U.S. Fish and Wildlife Service, National Marine Fisheries Service, and U.S. Forest Service all supported use of the ALP and approved the draft communication protocol. In addition, the license applicant noted that it would send a copy of the ALP request to all members of the Takatz Lake Project participant list (City 2009).

In FERC's response, granting the license applicant's request to use the ALP, it noted the support shown from notice respondents and stated the use of the ALP was appropriate because it "would foster improved communications, participation, and cooperation among the participants, and ultimately simplify and expedite the licensing process" (FERC 2009).

\subsubsection{Request and FERC Approval to Use the ALP for New License (Relicense)}

In May 2015, the existing licensee of the Weber Hydroelectric Project (FERC No. 1744) filed an NOI, PAD, and request to use the ALP for a new license (relicense) of an existing 3.85-MW hydropower project on the Weber River in Weber, Morgan, and Davis Counties in Utah. The project, partially located on federal lands within the Wasatch-Cache National Forest managed by the U.S. Forest Service, includes a 27-ft. x 79-ft. concrete diversion dam with radial gates and an intake structure creating a total width of $114 \mathrm{ft}$, a 9,107-ft. long steel pipeline, a 3-ft. x 118-ft. non-operative fish passage structure used to pass minimum flow, a powerhouse, a discharge pipe, and a 77-ft. long transmission line. The licensee's request to use the ALP for a new license only cited support of the key project stakeholders to use the ALP process because it fosters a collaborative negotiation process.

In the PAD, the licensee included the potential effect of water flow due to climate change, disrupting upstream fish passage, disturbing cultural resource sites, and the adequacy of existing recreation resources as existing environmental issues (PacifiCorp 2015). Proposed studies in the PAD included the effects that climate change may have on water flow, a water quality evaluation, an evaluation of Bonneville cutthroat trout and bluehead sucker movement to determine their ability to migrate (and more generally, identification of which species need passage upstream), a sensitive plant survey, surveys of the yellow-billed cuckoo and smooth green snake, a field survey identifying possible cultural resources, and an assessment of recreational needs.

In FERC's response, granting the licensee's request to use the ALP, it noted that the licensee tried to contact all appropriate project stakeholders and that all notice respondents approved the use of the ALP, including Reclamation and the U.S. Forest Service, as well as state agencies and non-governmental organizations (NGOs). Similar to the Takatz Lake Project, FERC stated that the use of the ALP was appropriate because it "would foster improved communications, participation, and cooperation among the participants, and ultimately simplify and expedite the licensing process" (FERC 2015a) 


\subsection{Request and FERC Denial to Use the TLP (Requirement to Use the ILP)}

This section highlights examples of projects in which the license applicant requested to use the TLP but received a denial to use the process from FERC based on the TLP approval criteria discussed in Sections 2.2 and 3.1. As a result, this section provides context as to why FERC may require the ILP for certain hydropower projects.

\subsubsection{Request and FERC Denial to Use the TLP for Original License}

In September 2011, the license applicant for the Bryant Mountain Pumped Storage (FERC No. 13680) filed an NOI, PAD, and request to use the TLP for an original license to construct a 1,250-MW pumped storage project located on Klamath Lake in Klamath County, Oregon (Bryant Mountain, LLC 2011). The project, located on Reclamation and private lands, proposed to use the existing Pope Reservoir as an upper reservoir, create a lower reservoir located at the foot of Bryant Mountain, and use Reclamation's " $D$ " and "A" canals to fill the project reservoirs. In addition to the lower reservoir, the project would require construction of transmission lines, improvements to access roads (under the jurisdiction of the Bureau of Land Management $[\mathrm{BLM}])$, power tunnels, a powerhouse, penstock, a water supply line, and groundwater wells.

In the PAD, the license applicant listed several existing environmental issues, including soil disturbance and soil erosion; fish entrainment; destruction of aquatic and wildlife habitat including the elimination of 1,500 acres of pasture, hayfield, and wet meadow and 200 acres of juniper woodland; recreational access limits; harm or destruction of sacred land used for religious purposes by the Klamath Tribes; and potential effects to 10 endangered or threatened species and 5 endangered or threatened plant species (Bryant Mountain, LLC 2011). Proposed studies included in the PAD were transmission line corridor alternatives, assessing the geological foundations of the proposed site to avoid fault lines, determining the amount of water needed, monitoring and modeling water quality, conducting a plant and animal survey including those that are endangered or threatened, nesting and wintering raptor surveys, and sensitive wildlife surveys.

The license applicant's request to use the TLP for an original license cited the following factors:

- Likelihood of timely license issuance: The license applicant believed use of the TLP would reduce stakeholders' and state agencies' demands to meet rigid deadlines. Any failure to meet such deadlines could set the project back several years or lead to cancellation of the project.

- Complexity of the resource issues: The license applicant believed minimal resource issues existed at the project site. Further, the use of the TLP would allow for a less-burdensome resolution of disputes with agencies and stakeholders.

- Level of anticipated controversy: Based on the information from stakeholders, the license applicant believed there was a low level of controversy.

- Relative cost of the TLP to the ILP: The license applicant believed the TLP would allow for completion of the license application in less time while significantly reducing labor-intensive scoping and, therefore, costing less than the ILP.

- Amount of available information and potential for significant disputes over studies: Though no significant disputes are anticipated, the license applicant stated they were committed to conducting the necessary studies regarding effective evaluation of all relevant issues. 
(Bryant Mountain, LLC 2011)

During the notice and comment period, the U.S. Department of the Interior (DOI), representing the BLM, submitted comments expressing concerns over the use of the TLP for licensing the Bryant Mountain Pumped Storage Project (U.S. DOI 2010). The DOI cited concerns over the expected impact that the project would have on BLM's public lands and resources. The concerns entailed cultural resources and protected sites of the Klamath Tribe that could be significantly damaged by the project, whether the volume of water under Reclamation's water rights claim could accommodate the project's water volume requirements and if the project would align with the Klamath Falls Resource Area Resource Management Plan. The DOI/BLM recommended that the license applicant consult with Klamath Falls Resource Area to discuss any proposed ground disturbing actions, including the need for additional studies, before moving forward with the project.

FERC denied use of the TLP process because numerous comments ${ }^{6}$ indicated that the complexity of the resource issues and the level of anticipated controversy are high. Because of the controversial and complicated nature of the project, FERC determined that the ILP process would be most appropriate (FERC 2012).

\subsubsection{Request and FERC Denial to Use the TLP for New License (Relicense)}

In September 2017, two separate license applicants for the existing Lower Mousam River Project (original FERC No. 5362; new FERC No. 14855) filed an NOI, PAD, and request to use the TLP for a new license (relicense) of a 600-kW run-of-river hydropower project on the Mousam River in Kennebunk, Maine, after the existing licensee filed an NOI to not file an application for a subsequent license. The project included three separate concrete gravity dams, each with their own powerhouse and small storage ponds (sub 25-acre), and no transmission/interconnection lines because the generated power was delivered straight into stepdown transformers and then into the distribution system (Save the Mousam: Keep the Kennebunk Dams, LLC 2017).

The first license applicant's PAD included nine endangered or threatened species that have a high possibility of being in the project area and existing dissolved oxygen and certain toxic substances in the river as existing environmental issues (Save the Mousam: Keep the Kennebunk Dams, LLC 2017). Proposed studies listed in the first license applicant's PAD included an examination of existing water quality, the extent of spawning and rearing habitat above Mousam dam, and an inventory of the vernal pools in the project area (Save the Mousam: Keep the Kennebunk Dams, LLC 2017).

The first license applicant's request to use the TLP for a new license cited the following factors:

\footnotetext{
${ }^{6}$ In addition to the DOI, commenters expressing concern with the use of the TLP included the Klamath Irrigation District, the Tulelake and Malin Irrigation Districts, the Klamath tribes, the Oregon Water Resources Department, and the Oregon Department of Fish and Wildlife (see OWRD 2011 ODFW 2012).
} 
- Likelihood of timely license issuance: The first license applicant did not provide a direct response on the likelihood of timely license issuance but instead focused on its desire to save the existing dam and work collaboratively with the public utility, town of Kennebunk, and existing licensee.

- Complexity of the resource issues: The first license applicant identified issues that it felt were common but that may need to be addressed during relicensing, including threatened and endangered species, compatibility of target species for fish passage, public recreation access, and cultural resources.

- Level of anticipated controversy: The first license applicant noted the greatest controversy would surround fish passage for four identified diadromous fish species. The license applicant also noted the small nature of the project, "one-sided studies" against the project, and the resource agencies' "questionable knowledge" of the Mousam River basin.

- Relative cost of the TLP to the ILP: The first license applicant believed the project would reduce costs relative to the ILP through a reduction of repeated studies and analysis. In addition, the license applicant desired to use the TLP to time some of the relicensing and scoping efforts concurrent with a process in which the town's residents would take over ownership of the dam.

- Amount of available information and potential for significant disputes over studies: The first license applicant indicated that baseline information exists for environmental resources in the Lower Mousam River, although specific environmental issues would require studies. The license applicant also indicated a willingness to work with stakeholders should significant disputes arise and enter the TLP dispute resolution process if necessary.

(Save the Mousam: Keep the Kennebunk Dams, LLC 2017)

The second license applicant's PAD listed a number of aquatic and terrestrial species (included threatened, endangered, and candidate species) but stated that there are no new environmental issues and proposed no studies at the time. However, the second license applicant acknowledged additional studies may be required in response to new information received in response to the PAD (America First Hydro LLC 2017). Specifically, the second license applicant's PAD stated that the license applicant anticipated no new adverse impacts or issues to fish and aquatic resources, wildlife or habitat, recreation, aesthetic, or cultural resources (America First Hydro LLC 2017).

The second license applicant's request to use the TLP for a new license cited the following factors:

- Likelihood of timely license issuance: The second license applicant believed the TLP's threestage consultation process would provide the flexibility required to conduct consultations, public meetings, and requisite environmental studies prior to the license application filing deadline.

- Complexity of the resource issues: The second license applicant believed the complexity of resource issues was similar to other projects going through or having completed relicensing in Maine (e.g., dam removal, decommissioning, fish passage, minimum flows, water quality), and the TLP is adequate for addressing these issues in a timely manner and has been successful in doing so in the past.

- Level of anticipated controversy: The second license applicant noted six commenters or interveners for the project and framed the issue as one of "renewable power versus dam removal." 
- Relative cost of the TLP to the ILP: The second license applicant noted that the TLP will be more cost effective and straightforward for the completion of necessary studies than would be possible using the ILP.

- Amount of available information and potential for significant disputes over studies: The second license applicant did not anticipate study disputes for either the types of studies or scope of studies based on its literature and data searches and reviews of similar relicensing proceedings. In addition, the license applicant noted that any potential disputes would likely involve the costs for improvement/replacement of project works and/or mitigation measures and the impact of those costs on the economic viability of the project, which fall under FERC's purview and would not benefit from use of the ILP.

- Other pertinent factors: The second license applicant had significant experience with all three licensing processes, and based on prior experience, the size, potential controversy, and complexity of the project does not warrant the "more complex and costly" ILP process.

(America First Hydro LLC 2017)

During the notice and comment period, the National Oceanic and Atmospheric Administration (NOAA)-Fisheries submitted comments opposing the use of the TLP for relicensing of the Lower Mousam River Project (NOAA 2017). NOAA cited that the ILP is the default process, and deficiencies within the TLP for projects such as this is what led to creation of the ILP. Specifically, NOAA anticipated the license proceeding would be complex and controversial due to local interests to remove the dams, interest in creating fish passage and establishing bypass flows, and/or restoring fisheries as well as sea-run fish to the Mousam River. In addition, NOAA-Fisheries noted that two competing license applications were being developed for the site, which may result in duplicative processes and conflicting filings that require time to resolve. $^{7}$

In FERC's response to the first license applicant, FERC denied the TLP request and altogether dismissed the NOI and PAD for lack of an unequivocal statement that the first applicant would actually file a license application (FERC 2017a).

In FERC's response to the second license applicant, FERC denied the TLP request based on the likelihood for the proceedings to involve complex and controversial resource issues that could lead to study disputes and impact timely license issuance. FERC appeared to rely heavily on opposition comments from NOAA (discussed above) and the following reasons provided by two environmental NGOs and supported by 11 additional NGOs as well as two Indian tribes.

- Likelihood of timely license issuance: The second license applicant did not support a claim that the ILP is too inflexible for timely issuance.

- Complexity of the resource issues: Complex issues, including dam removal and fish passage, were raised by multiple organizations.

${ }^{7}$ A license applicant filed a competing NOI, PAD, and TLP request to take over licensing of the project (FERC No. 14856). 
- Level of anticipated controversy: The level of controversy was anticipated to be intense, and the ILP (unlike the TLP) provides study dispute resolution to all participants - not only resource agencies and tribes.

- Amount of available information and potential for significant disputes over studies: Under the TLP, the license applicant could refuse stakeholder study requests, leading to a potential stalemate between stakeholders.

- Other pertinent factors: The structured schedule and transparent documentation provided through the ILP is required in this proceeding.

(FERC 2017b) 


\section{Potential Advantages and Challenges of Each Licensing Process}

This section highlights potential advantages and challenges commonly associated with each of FERC's three licensing processes.

\subsection{ILP Potential Advantages and Challenges}

Potential advantages to using the ILP may include the following:

- Coordination of multiple resource agency permitting processes

- Establishment of a formal timeframe for all stakeholders to complete the steps necessary for FERC licensing

- Assurance that all interested stakeholders will have an opportunity to participate in the FERC licensing process at clearly specified times over the course of the licensing process

- Early scoping, which helps reduce the number of study and information requests made later in the FERC licensing process, after the license applicant has filed a FERC license application, which may lead to additional time and resources expenditures.

Potential challenges to using the ILP may include the following:

- Although strict deadlines imposed by the ILP may be helpful to keep participating stakeholders on task, these deadlines may also prove unworkable under some circumstances

- The ILP may require more time

- The ILP may be more expensive.

\subsection{TLP Potential Advantages and Challenges}

Potential advantages to using the TLP may include the following:

- The TLP provides more flexibility for the license applicant and interested stakeholders to complete various steps in the licensing process because it does not have a strict timeline

- The TLP may be more efficient than the ILP for non-controversial projects without significant environmental concerns

- The TLP may be less costly than the ILP.

Potential challenges to using the TLP may include the following:

- Interested parties may find it difficult to know when they can participate in FERC's decisionmaking process without a formal licensing schedule

- FERC staff generally does not assist the license applicant in completing the FERC license application or coordinating pre-filing meetings, scoping, and study requests

- Important issues identified during FERC's NEPA scoping process may not be adequately studied under the license applicant's study plan

- Without a strict timeframe, resource agencies and other participating stakeholders may request additional studies or information requests later on in the FERC licensing process. 


\subsection{ALP Potential Advantages and Challenges}

Potential advantages to using the ALP may include the following:

- Without a strict timeline, the license applicant and other interested stakeholders have greater flexibility to complete various steps in the licensing process

- Allows the license applicant and stakeholders to combine the consultation, study, and environmental review processes

- Earlier scoping and the development of a collaborative preliminary draft NEPA document (applicant-prepared EA or EIS) may help interested parties to clarify and resolve issues relating to controversial projects

- FERC staff are available to advise the license applicant and other interested stakeholders as they work together to complete pre-application activities.

Potential challenges to using the ALP may include the following:

- Interested parties may find it difficult to know when they can participate in the decision-making process

- Generally, requires the license applicant and stakeholders to reach a consensus on required studies

- Without a strict timeframe, resource agencies and other participating stakeholders may request additional studies later on in the FERC licensing process

- Important issues identified during FERC's NEPA scoping process may not be adequately addressed in the license applicants preliminary draft EA or EIS

- The process generally requires all major stakeholders to agree to a comprehensive settlement agreement and is highly dependent on consensus-building between stakeholders prior to submitting the NOI and PAD. 


\section{Conclusion}

Determining which of FERC's three licensing processes best matches an individual project's attributes is a major consideration prior to initiating the FERC licensing process. When seeking to use the TLP or ALP, a license applicant must review the regulatory criteria for TLP/ALP approval (as discussed in Section 2.2.1) to determine whether the process is appropriate and if the license applicant has met the regulatory requirements described in 18 CFR $\S 5.3$ (c).

As discussed in Section 3.3, FERC has denied use of the TLP and required the default ILP, particularly where the PAD and/or comments received on the request to use the TLP indicated the complexity of resource issues, the level of anticipated controversy, and/or the potential for study disputes was high.

As demonstrated in Section 3.2, the ALP remains a viable tool for projects in which stakeholder disagreements are minimal and a collaborative process with a flexible timeline is preferred.

In sum, license applicants continue to utilize all three licensing processes for both original and new hydropower licenses, but not all licensing processes are appropriate for all non-federal hydropower projects. 


\section{References}

America First Hydro LLC. 2017. America First Hydro LLC's Notice of Intent, Pre-Application Document and Request to use the Traditional Licensing Process for the Relicense of the Lower Mousam River Project - FERC Project No. 14855. September 12, 2017.

Bryant Mountain, LLC. 2011. Bryant Mountain, LLC's Notification of Intent, Pre-Application Document, and Request to use the Traditional Licensing Process for the Bryant Mountain Pumped Storage Hydroelectric Project - FERC Project No. 13680. September 1, 2011.

CBHP (Columbia Basin Hydropower). 2016. Columbia Basin Hydropower Notice of Intent, PreApplication Document, and Request to Use the Traditional Licensing Process for the Banks Lake Pumped Storage Project - FERC Project No. 14329. June 27, 2016.

City (City and Borough of Sitka Electric Department). 2009. City and Borough of Sitka Electric Department's Filing of Pre-Application Document, Notice of Intent, and Request to Utilize Alternative Licensing Procedures for the Original License of Takatz Lake Hydroelectric Project - FERC Project No. 13234. March 20, 2009.

Cowan, Laura. n.d. "The Three Relicensing Processes: Kleinschmidt's Experience and Recommendations to Licensees.” Deerfield, IL: Kleinschmidt Group. https://www.kleinschmidtgroup.com/files/8113/9721/9442/The Three Relicensing_Processes KAs_Experience and Recommendations to Licensees___LJC.pdf.

FERC (Federal Energy Regulatory Commission). 2004. "Handbook for Hydroelectric Project Licensing and 5 MW Exemptions from Licensing." Washington, D.C.: Federal Energy Regulatory Commission. https://www.ferc.gov/industries/hydropower/geninfo/handbooks/licensing handbook.pdf.

- 2009. Federal Energy Regulatory Commission Authorization to City and Borough of Sitka Electric Department's for Use of Alternative Licensing Process for the Original License of Takatz Lake Hydroelectric Project - FERC Project No. 13234. April 28, 2009.

—. 2012. Federal Energy Regulatory Commission Order Denying Bryant Mountain, LLC's Request to use the Traditional Licensing Process for the proposed 1,250-megawatt at Bryant Mountain Pumped Storage Hydroelectric Project - FERC Project No. 13680 (January 31, 2012).

- 2015a. Federal Energy Regulatory Commission's Authorization to PacifiCorp to Use the Alternative Licensing Process for the Relicense of Weber Hydroelectric Project - FERC Project No. 1744. (August 13, 2015).

. 2015b. "FERC Licensing Processes." Presented February 24, 2015. Washington D.C.: Federal Energy Regulatory Commission. https://www.fws.gov/northeast/ecologicalservices/pdf/hydro/Carter_Licensing_Processes_and_N EPA Feb 2015.pdf. 
. 2016a. Federal Energy Regulatory Commission Authorization for Puerto Rico Electric Power Authority to Use the Traditional Licensing Process for the Rio Blanco Hydroelectric Project - FERC Project No. 663. (October 7, 2016).

2016b. Federal Energy Regulatory Commission Response to Southern California Edison's Notice of Intent to File License Application and Filing of Pre-Application Document Approving Use of the Traditional Licensing Process for the Banks Lake Pumped Storage Project - FERC Project No. 14329. August 31, 2016.

2017a. Federal Energy Regulatory Commission Order Dismissing Notice of Intent, PreApplication Document and Request to Use the Traditional Licensing Project for the Lower Mousam Hydroelectric Project - FERC Project Nos. 5362 and 14855.

- 2017b. Federal Energy Regulatory Commission Order Denying America First Hydro LLC's 9/12/17 Request to use the Traditional Licensing Process for the Lower Mousam Hydroelectric Project - FERC Project No. 14856. (October 31, 2017).

—. 2017c "Matrix Comparing Three Licensing Processes." Washington D.C.: Federal Energy Regulatory Commission. https://www.ferc.gov/industries/hydropower/geninfo/licensing/matrix.asp?csrt=10103490111958140359.

Layman, Steven R., Fred E. Springer, and David M. Moore. 2006. "Selecting a Licensing Process: Which Approach is Best for Your Project?" Hydro Review (Oct. 2006).

https://www.troutman.com/files/Publication/7135edc6-c7d4-4998-9fc418e706d34a4e/Presentation/PublicationAttachment/861baeb5-58e9-4984-a6231bf8d5837e19/Springer-Moore\%20_LicensingProcess.pdf.

NOAA (National Oceanic and Atmospheric Administration). 2017. National Oceanic and Atmospheric Administration's Opposition to Traditional Licensing Process requests of Save the Mousam: Keep the Kennebunk Dams, LLC and America First Hydro, LLC for the Relicense of the Lower Mousam River Project - FERC Project Nos. 5362 and 14855. October 25, 2017.

ODFW (Oregon Department of Fish and Wildlife). 2012. Oregon Department of Fish and Wildlife's Comment on Bryant Mountain Pumped Storage Project - FERC Project No. 13680. January 27, 2012.

OWRD (Oregon Water Resources Department). 2011. Oregon Water Resources Department 's Comments on Bryant Mountain Pumped Storage Project - FERC Project No. 13680. September 29, 2011.

PacifiCorp. 2015. PacificCorp's Filing of Notice of Intent to File an Application for new License and Pre-Application Document to the Federal Energy Regulatory Commission for the Relicense of Weber Hydroelectric Project - FERC Project No. 1744. May 29, 2015.

Payne, Heather. 2017. “A Long Slog: What a Ten Year Hydroelectric Relicensing Process Demonstrates About Public Participation and Administrative Regulation Theories." 53 Idaho L. Rev. 41 (2017). http://www.law.unc.edu/documents/clear/publications/longslog53idaholrev41.pdf. 
PREPA (Puerto Rico Electric Power Authority). 2016. Puerto Rico Electric Power Authority's Request for Approval to Use the Traditional Licensing Process, Filing of Notice of Intent to File an Application of a New License and Pre-Application Document for the Rio Blanco Hydroelectric Project - FERC Project No. 663. August 11, 2016.

Save the Mousam: Keep the Kennebunk Dams, LLC. 2017. Save the Mousam: Keep the Kennebunk Dams, LLC's Notice of Intent, Pre-Application Document, and Request to use the Traditional Licensing Process for the Relicense of the Lower Mousam River Project - FERC Project No. 5362. September 8, 2017.

USDA FS (United States Department of Agriculture Forest Service). 2016. United States Department of Agriculture Forest Service - Southern Region Comment Requesting the Federal Energy Regulatory Commission Employ the Default Integrated Licensing Process for the Rio Blanco Hydroelectric Project - FERC Project No. 663. September 09, 2016.

U.S. DOI (United States Department of the Interior). 2010. United States Department of the Interior Comments on Notice of Application for a Preliminary Permit for the Bryant Mountain Hydroelectric Pumped Storage Project - FERC Project No. 13680. July 15, 2010. 